\title{
RELIGIONS IN AFRICA
}

\author{
Conflict and Coexistence
}

\section{Thomas Molnar}

Our story-book coneept of Africa as the "dark continent" is no longer valid. Nor is that other storybook notion, "man against wild beasts." The sad fact is that Africa today is, and will probably be even more in the future, the scene of savage conflicts between black men and black men, Arabs and other. Arabs, Moslems and Animists, Christianity and Islam. For a while the race issue in South Africa obscured the fact of antagonisms and hostilities elsewhere; sinee the horible acts of torture and cannibalism occurred in the Congo, the world can no longer ignore the eruption of multi-layered hatred, motivated by rice, religion, and ideology, in practically every corner of Africa.

But these are conflicts essentially of a political nature-the reader might say. The truth is that religion, broadly defincd, is present in them, often as the central issue. Africa is still tribal, and the tribe is a religious unit too, having its own cult, fetishes, protective spirits, magic secrets and techniques. Often even "Westernized" Arabs and black Africans have a kind of natural religiosity, compounded by magic, superstitions, and the mores of tribal or family life. This is not evident when we meet Africans in our midst: diplomats, students, and other sophisticated travelcrs. But these men and women, re-immersed in their original milieu, discard much of the Western veneer and conform to the milieu's expectations. Religiosity thus reasscrts itself at contact with the tribe and what anthropologists call the "extended family": these are not communities in the Western sense, but extremely strong cohesive groups, political and economic units, but also centers of cult.

Religion in Africa has much to do with race. In spite of long French, and also British ts well as Italian presence in North Africa, the Arabs have proved almost completely impermeable to Christianity. Mohammed's and the Caliph's conquering troops had largely exterminated the flourishing Christian communities, and North Africa, from Marrakech to Luxor, is today uniformly Moslem. At first sight the traveler finds no deep commitment to Islam.

Mr. Molnar, author of Africa-A political Travelogue and other books, is a member of the French Department at Brooklyn College.
Idcologies: Marxism, "Arab Socialism" (whatever it means), Nasserism, Bourguibism (whatever they are) scem to be the real agitating factors, popular conversation topics around the tiny tables of all-day coffee drinkers. More than that the rural exodus, the increasingly generalized habit of drinking alcoholic beverages (contrary to Islam's teaching), the loosening of family ties, seem to compel religion to accept a secondary role.

Yet, paradoxically, religion is everywhere present. In Tunisia, Bourguiba tries to secularize society and orders businesses and government offees to work during the day in the month of the Ramadan. But not much work is done in most of them: the climate encourages indolence, and is a secret friend of Islam, by no means an "activist" religion. Nor can the new chiefs of state ignore religion: a Hassan II and his sisters may not be different in outlook and mode of life from French aristocrats; a Nasser, a Ben Bela may be radical revolutionary leaders; yet their nationalism cannot be imagined, without religious undertones, and for every socialistic slogan they must launch another one, appreciated by the strong religious fraternities, by peasants and small artisans.

One cannot say, on the other hand, that Islam does much, if anything, for the latter on the plane of social and economic well-being. It is, rather, a force of reaction, although it may serve as partial inspiration for revolutionary movements at their beginning (as with the Naguib-Nasser plot). The dynamic relgion here is still Christianity. The maribout (Moslen teacher) is not a center of attraction for people who wish to achieve a better life; it is the Christian mis. sionary who creates and maintains schools, vocational centers, homes for unwed mothers, hospitals, and many other institutions.

Today, after the retreat of colonial powers, the white priests and religious are no longer suspected of serving foreign interests. On the other hand, they live and work in a religiously hard and resistant en. vironment. The result is that the Church's role and influence may have reached their historically lowest point in the North African world. Of the more than one hundred and twenty Catholic churches of Tunisia, for example, only five are now open through 
"arrangements" with the Vatican, and tha famous st. Louis Cathedral, at Carthage, has been confiscated by Tunisian authorities and turned into a museum. Men like Cardinal Duval of Algiers who openly took the F.L.N, side against the local French in the last years of the Algerian war, now renlize that they haye been used. No gratitude is shows, and certainly no new implantation of Christianity in Algerian soil is allowed.

Christianity has a far greater-and continuedgood chance in black Africa. This has several aseertainable causes. One is the age-old antagonism between Arab and black. From afar, "colored" Africa may appear united against the white man; on the spot things look vastly different even if, for political and propagandistic reasons, Arab and black politicians refer to each other as "brothers." The historical memory of blacks tells them of Arab slave traders and their raiding parties, and also of the contempt in which the civilized Arab lords held the black man. These lords usually kept black bodyguards and palace grards because these soldiers were necessarily loyal to them, their sole protectors against hatred-flled Arab populations. Today both sides are supposed to be modem and independent. Yet black Africans suspect the Arabs of ncw tricks, this time not as slave traders but as imperialists. And Islam is, of course, identified with the Arabs and their hunger for conquest.

Several black States are officially Mohammedan (Mali, for example), and others have substantial Moslem minorities. But for historical and geographical reasons such a religious coexistence is, at times, most precarious, even dangerous for one or the other side. In Sudan the northern Arabs planned a fow years ago a veritable genocide against the Clristian blacks of the south. Even today these Christian Sudanese must carry passes.

Christian Ethiopia is under pressure from Nasser's Egypt, and in this pressure the religious element is not absent. Farther down, in the Congo, all lcaders, whether Kasavubu, Adoula, or Tshombe, know well that the arms and diplomatic support the rebels of the Eastern provinees received from Nasser and Ben Bela are instruments of Arab infiltration in the rich Congo Basin. Every Egyptian teacher and ulema sent by Nasser in Central Africa is stispected, rightly, by the black leaders as a carrier of Arab imperialism. When Ben Bella offered to send ten thousand soldiers to help Adoula strengthen his regime, the latter managed to refuse this Trojan horse: acceptance would have made lim far more unpopular among bis non-Moslem supporters than the white auxiliary forces could ever make Tshombe.
If the black men in Western and Central Africa are apprehensive about Arab designs, black men in East Africa fear and dislike the British-implanted Indians. A Ugandan admitted: "What the Jews were for Hitler, the Indians are for us." Is this a question of religion? In a sense, it is, at least as a factor informing the Indian's cultural and family life, solidarity with fellow-Indians, his haughty feeling of separation and superiority. For the Indian (as for the Chinese) the black man is an inferior being: in India and China dark skin denotes lower status. When religious-magic-racial cruptions occur in Africil, as in Zanzibar, Kenya, or the Congo, they are directed with particular savagery against Indian communities, villas and stores. In 1949 Zulus in Durban, South Africa, exteminated close to a thousand Indians in one day, although they did not touch whites and Clinese.

\section{-}

The African blacks are mostly Christian or Animist. Generatly speaking, stable, sedentary populations adopt attitudes which prepare the ground for conversion to monotheism. On the contrary, migratory populations, like the Masai in Kenya, have a rougher outlook on life. Let me citc an cxample of what unexpected results in the moral domain seemingty remote phenomena may have: the availability now of condensed milk for child feeding has reduced the long duration of breast fceding (usualiy two years). The husband who used to take a scond wife during the lactation period, now tends to remain monogamous. Islam, on the other hand, tempts non with the permission, even obligation, to have scveral wives. This is looked upon favorably by fammers whose work on the fick is traditionally done by women and chifleren-and the more of them, the bettert

One learns interesting details about hlack Africun Christian life. The clergy is increasingly rechruited among natives, and the liturgy, musie, for exam. ple, becomes "Africmized" too. The clergy is in tensely nationalistic which is quite natural in the present circumstances of the continent; but this has some unpleasant by-products, such as the easy-going ways Africans generally have with common funds. Moneys sent from Rome for construction, saluries and other expenses in schools, hospitals, convents, etc., are not always spent for the appointed purposes. Mismanagement and irresponsibility, the double plague of the new African, clite, are prescnt among the new hierarchy too. The other side of the coin is the exemplary obedience and devotion of black nuns, in the spirit of African women. 
There are, of course, many problems. There are black priests living in concubinage, although it was a black bishop who warned the Council not to relax the celibacy rules. Even racial diseriminationamong blacks-is not a rare phenomenen: the Catholics of Urundi despise the pygmies and refuse to take communion in their company.

All told, the future of Christianity in black Africa secms assured. Outside the religious aspects, Christianity provides a certain political stability, links with the West, and social-economic dynamism. During the colonial period many people became Christians or sent their children to missionary schools for advantages accruing from direct contact with the white man. Such opportunistic reasons are no longer valid, or at least much less than in the past. Thus there may now follow a period of quantitative shrinkage of Christian life and activity in Africa. However, this situation, if it develops at all, may not be a last. ing one. For example, Communist anti-religious propaganda, directed at Africans in the belief that they would repudiate the "white man's religion" has dismally failed, because it questioned clumsily the black man's genuine religious option.

Islam is a more serious threat. Because it makes fcwer demands and becauge it is still a minority religion among blacks it crentes an intense solidarity among adhering blacks, whether in Nigeria where Moslem blacks look down on Christian ones-and, in the North, segregate them-or in Tanzania where half of the ruling party deputies ure of Islamic faith. Generally, such is the importance of Islam in. East Africa that the Red Chinese have published a Swapili-language edition of the Koran (with footnotes suggesting a new prophet's arrival from the East).

The probability is that not Islam but the animistic elements of black Africans' ancestral religion will put the deepest mark on the religious future of twothirds of the continent. These animistic elements, for example, ancestor worship, will infiltrate the faith of African Christians too. This would be, a familiar phenomenon

It is too early to tcll what definitive forms African Christianity will take. It should be noted that animism, magic, fetishism, sometimes cven cannibalism, are close to the surface. In recent years, Felix Houphouet-Boigny, president of Ivory Coast, had to forbid several instances of new cults whose eenter he had become, unknown to him. In another case a provincial official admitted participation at a tribal cannibalistic meal. As an extenuating circumstance he pleaded that he had only eaten a little finger of the old womas who was on the memu.

These are the somewhat grotesque surface mani- festations of an otherwise undeniable phenomenon: the conflict of two (or more) worlds, and religious worlds too, in today's Africa, According to some white bishops the progress of detribalization and modernization is being pushed too fast, but they admit that the churches must keep pace if they do not want to hear charges of "reaction." The some ninety Catbolic black bishops today are proof that the Vatican does not wish to remain behind in the race, although their administrative capacity, as distinct from their eloquence and fervor, is generally low: In Windhoek (South West Africa) the first native theologian, a man of great promise, has just returned. from Fome. His tribe is still largely agricultural and has only a handful of university graduates.

One appreciates these advances only after realizing the tremendous hold of the ancestors and of magic on the African mind. Masses of nominally Christian natives do not consult doctors and hospitals unless the local witch doctor allows them to, al. though the permission may come too late and the disease remairs incurable. In which case the witch doctor can say, "I told you so!" Tribes moving to a new territory, even if more fertile and advantageous, may perish in a matter of years because the witch doctor, who for some reason opposed the move, had laid a curse on the place in the name of the abandoned ancestors and their gravesites.

Can such people be made into Christians? I asked an old missionary: "Have you converted many natives?" "Oh, certainly, thousands," he answered. "But as far as Christianizing them," he added with a good humored smile, "the figure is smaller. Let me see," and he raised the fingers of two hands. I said: "You mean ten?" He hid one hand, leaving only five fingers: "That's about it," he answered.

An cducated black man said: "You Europeans boast of Christianizing Africa and display your statistics of church attendance. But you cannot reach the soil, the language, the habits through which our ancestors speak to. us." When Kaizer Matanzima, chief minister of the Transkei, was congratulated by his brother on his electoral victory, he answered: "The spirits of our ancestors helped me," Yet in spite of these statements, Christianity is decply anchored in Africa. In most parts it has become a synonym of progress, not in terms of steel mills and airlines, but of a much more genuine progress: education, permanent settlements, family life. The mission station is still a symbol of leadership and resourcefulness where skills and crafts may be learned, where girls are taught to prepare their trousseau and care for their babies, where the sick are relieved of their plight. 